\title{
Tüketim, Postmodernizm ve Kapitalizm Örgüsü
}

\section{Songül Demirel}

\section{Hitit Üniversitesi}

sungurlu Meslek Yüksekokulu

songuldemirel@hitit.edu.tr

\section{Ceren Yegen}

Muș Alparslan Üniversitesi

iletișim Fakültesi

c.yegen@alparslan.edu.tr

\section{Öz}

Tüketim insanın olduğu her yerde mevcuttur. Bir alıșkanlık olarak tüketim, bireylerin gündelik yașam pratiklerinin neredeyse tümünü kapsamaktadır. Son yıllarda kapitalizm ve postmodernizmden aldığı güç ile artan tüketim ve değișen tüketim alıșkanlıkları, bir kavram olarak tüketim olgusu üzerine düșünme gerekliliğini doğurmuștur. Bu yüzden bu çalıșmanın amacı da tüketim kavramı temelinde, söz konusu kavrama ivme kazandıran kapitalist ve postmodern süreçlerin anlașılmasıdır. Bu sayede kapitalizm ve postmodernizmin tüketimi nasıl ördüğü ve meșrulaștırdığı anlașılmaya çalıșılacaktır. Çalıșmada bireylerin nasıl ve neden tükettikleri sorularının cevapları da aranacaktır. Böylelikle tüketim kavramı birçok çerçevede irdelenecektir. Çalıșmada ayrıca bireylerin tüketimi bir kimlik ya da statü inșa etme aracı olarak görmeleri varsayımı ile medyanın tüketim sürecindeki rolü de ele alınacak, bir tüketim yönlendiricisi olarak medyanın tüketimi nasıl teșvik ettiği incelenecektir.

Anahtor Kelimeler: Tüketim, kapitalizm, postmodernizm, kimlik, medya.

Makale geliș tarihi: 29.09.2014 • Makale kabul tarihi: 25.03.2015

http://ilefdergisi.org/2015/2/1/

ilef dergisi • ( ) 2015 • 2(1) • bahar/spring: 115-138 


\section{Consumption, \\ Postmodernism and the Pattern of Capitalism}

\section{Songül Demirel}

Hitit University

Sungurlu Vocational High School

songuldemirel@hitit.edu.tr

\section{Ceren Yegen}

Muș Alparslan University

Faculty of Communication

c.yegen@alparslan.edu.tr

\section{Abstract}

Everywhere people exist does consumption. Consumption covers all aspects of people's daily life. Consumption habits increased by the power they get from capitalism and postmodernism recently, make it essential to think about the consumption as a phenomenon.. Therefore the purpose of this study is to understand capitalist and postmodern processes in the context of consumption phenomenon. Thus this study tries to understand how capitalism and postmodernism build and legitimatize consumption. In this study, the questions of why and how people consume will be examined. Hereby, the concept of consumption will be analyzed from different perspectives. Based on the assumption that individuals regard consumption as a way of building identity and social status, the role of media in promoting consumption will bea ddressed.

Key Words: Consumption, postmodernism, capitalism, identity, media. 
Yirminci yüzyılın başlarında mal ve hizmet üretenlerin temel kaygisı daha çok, üretimi artırabilmek için verimliliği nasıl artıracaklarının yolunu bulabilmekti. Taylor ve Ford'un çalışmalarının odağı hep daha fazla üretebilmekti. Nitekim azgelişmiş ve gelişmekte olan ülkelerdeki pazarların ürün talepleri devam etmekteydi. Üretilen ürünlerin beğenilmeme veya alıcı bulmama durumuyla henüz karşılaşılmamıştı. Gelişmiş ülkelerden, gelişmemiş ve azgelişmiş ülkelere doğru ürün ihracatı, ürünlerin niteliği değişmekle beraber günümüzde de hâlâ devam etmektedir.

İlk kez 1929 Ekonomik Buhranında işletmeler, pazarlayamama problemleriyle karşılaşmışlardır. Maliyetleri kısmak için, işçi çıkarmalar ve kalan işçilerin ücretlerini düşürme de dâhil olmak üzere birden çok tedbire başvurmuşlardır. Dönemin üretim sorunları olan neyi, nasıl, kiminle, neyle ve ne kadar üretileceği ilerleyen yıllarda değişmiştir. 1950'li yıllara gelindiğinde üretimden ziyade tüketimin arttırılması gündeme gelmiş, tam da bu noktada pazarlama stratejileri imdada yetişmiştir.

20. yüzyılın yarısına gelindiğinde, sermaye ve emek ikileminin sahipleri, üretim ve tüketim gibi tamamen ayrı iki kavramı beraber kuşatan bir boyut için, çözüm aramak zorunda kalmışlardır. Önceleri tüketmek için üretim 
yapılmakta iken şimdilerde üretilebilmesi ancak tüketilebilmesi ile mümkün hale gelmişti. Döngü ancak böyle gerçekleşebilirdi.

Bu çalışmada 1980'li yılların tüketim toplumundan günümüzün tüketimci toplumuna, yaşanan sürecin değer ve algıları analiz edilmeye çalışılacaktır. Çalışma geçmişten günümüze tüketim kavramının tartışılması üzerinden kurulmaktadır. Bu konu kapsamında; bir üründen bir diğerine almak için koşan, elde edildiğinde ise değersizleşen bir alısveriş kovalamacasının nedenleri irdelenecektir. Tüketim sürecinde medyanın oynadığı rol de popüler kültür ve tüketim kültürü kavramları çerçevesinde tartışlacaktır. Kuramsal çerçevesini kapitalizm ve postmodernizm tartışmalarının oluşturduğu çalışmada betimleyici bir yöntem kullanılacak ve tüketim kavramı derinlemesine ele alınacaktır.

Çalışmayı sürdürürken, tüketimin yönlendiricisi olan kapitalizmi ve durumu anlamlandırmak için postmodern toplumun sancılarını görmemiz gerekmektedir. Postmodern toplumun anlamsız, kimliksiz (ya da anlamsizlaştırılmış ve kimliksizleştirilmiş) insanının kendini anlamlandırma çabası tüketim üzerinden okunmaya çalışılacaktır. Kapitalizmin ve küreselleşmenin bu süreçte ölçülemeyecek etkileri tartışma götürmez gerçeklerdir ve bu yüzden bu çalışmanın kapitalizm ve postmodernizm kadar küreselleşme olgusunun anlaşılmasına da katkı sağlayabileceği düşünülmektedir. Çalışma ayrıca medyanın bir tüketim yönlendiricisi olduğu iddialarına cevap arayacaktır. Çalışmanın kapsamı salt tüketim ve etkenlerini anlama yönünde olmayacak, durumun yaşanılan dönemin pratikleriyle ilgisine de bakılacaktır.

\section{Kapitalizm ve tüketim}

Yeni uluslararası işbölümü yapısına yol açan gelişmeler, çoğunlukla Kuzey ülkelerinin bunalımından kaynaklanmaktadır. Yoğun birikim rejimlerinin yol aç九tğı eksik tüketim, kâr oranlarının düşmesine ve emek verimliliği ile ilgili sorunların ortaya çıkmasına neden olmuştur. Kaynakların dağılımı açısından dışa bağımlı olan ülkeler de, bunalımdan paylarına düşeni almışlardır. Gelişmekte olan ülkeler, Keynesçi politikaların sona ermesi üzerine yeniden dağıtım ve plânlama işlevlerini yerine getirememişlerdir. Öyle ki Güney ülkelerinin çoğunun sermaye, işgücü ve pazar yaratma kavgasının bloklaşma yönünde bir seyir izlemesi ve küresel dünya pazarı yerine, para birimi üzerinden bölgeler yaratması da, sanayileşmekte olan ülkeleri sıkıştırmıştır (Yentürk 1993, s.309). Böylelikle oluşan küresel ekonomik düzende ülkelerin üretim ve tüketimi tüm dünya ülkelerinin dâhil olduğu bu sistemi ilgilendirir duruma gelmiştir. 
Taylorizmin daha gelişkin bir türü olan Fordist model, kapitalizmin yapısal ve kurumsal örgütlenmesini yeniden biçimlendirmiş; öyle ki, başta üretimle toplumsal tüketim normlarının birbirine eklemlenmesi olmak üzere toplumsal ve ekonomik yaşam birbirine sıkıca bağlanmıştır. Keynesçi ekonomilerle bir arada gelişen Fordist emek süreçleri, toplu pazarlık ve sendikal örgütlenmelerin gelişmesini desteklemiş ve sınıf mücadelesinin kurumsallaşmasını sağlamıştır. Böylece ücretli emek yalnızca üretim ve emek süreçleri içinde değil, tüketim başta olmak üzere yaşamın her alanında sermayenin yönetimi altına girmiştir (Öngen 1993, s.319). Bu duruma paralel bir biçimde emek ve üretim olguları tüketimin de önünü açmıştır.

Kapitalizm, İkinci Dünya Savaşı'ndan sonra siyasal, ekonomik ve kültürel alanlardaki önemli dönüşümlerin nedeni olmuştur. Özellikle kültürel yapıyı oluşturan farklı kaynaklardan biri olan tüketim olgusu, kültürel yeniden yapılanma sürecinde değişerek tartışma konusu olmaya başlamıştır. Yeni kapitalizm artık üretim süreçlerine verdiği desteği, tüketim alanlarına kaydırmış, insanların çalışmak için ayırdıkları zamandan arta kalanı tüketime harcamalarını istemektedir. Kapitalizmin hedefi, boş zamanı maksatlı kullanmak ve yeni ideolojiler, değer yargıları ve kanaatler oluşturmaktır. Hegemonik bir iktidara dönüşen kapitalizm, durumu farklı kanallar aracılığıyla kitlelere benimsetmeye çalışmaktadır (Aytaç 2004, s.116). Medya bu bağlamda birçok kişiye ulaşıp, etkileyebilecek ideal bir araç özelliğindedir ve kapitalist düzende hegemonik değerler ile ideolojileri bireylere hem ulaştırmak hem de kanıksatmak amacı ile kullanılan en etkili araç olarak başı çekmektedir.

Geçmişin üretici toplumuyla, günümüz tüketim toplumunun üyelerini şekillendirme biçimi her şeyden önce tüketici rolünü oynama gereksinimince belirlenir. Toplum üyelerine örnek normlar verilir, toplumda verilen bu normlara uygun rolü oynama yeteneği ve arzusu bulunmaktadır. Bauman'a göre (1999, s.40-41), tüketme arzusunun başlıca belirleyeni insanların sosyal kimliklerine ait talepleri karşılamak için hazırlanma ve eğitilme tarzları olmuştur. Bourdieu ise bunu "habitus" kavramıla açıklar; tüketim, habitusun işlevlerinden biri olan özel bir eyleyicinin ya da bir eyleyici sınıfının pratikleriyle mallarını/ varlıklarını birleştiren tarz birliğini aktarabilmektedir. Bir kimsenin yediği şey ve yeme biçimi, yaptığı spor ve yapma biçimi, siyasal kanaatleri ve ifade etme biçimi gibi birbirinden farklı olmakla beraber ayırıcı, sınıflandırıcı özelliklerdir (Bourdieu 2006, s.21). Tüketiciler bulundukları toplumsal sınıfın konumuna göre bir tüketim içerisine girerek tercihte bulunmaktadırlar. Burada toplumsal kültürü belirleyen üreticiler aynı zamanda tüketimin de belirleyicisi konumundadırlar. 
Öyle ki bugün itibariyle çalışma etiğinin yol gösterdiği bir toplumdan tüketim estetiğiyle yönetilen bir topluma doğru yönelim gerçekleşmekte, yoksullar, emeğine ihtiyaç duyulan bir toplum kesimi olmak yerine tüketemeyen bir toplum kesimi olarak düşünülmektedir (Bauman 1999, s.10). Tüketememekle de aslında topluma dair yararlı bir işlevi yerine getirmemiş olmaktadırlar.

\section{Bir sorun alanı olarak tüketim: Dikkatlerin üretimden tüketime çekilmesi}

Üretim birimlerinin ölçeğindeki ve mülkiyet birimlerindeki artış, üretimin, istihdamın vb. giderek artan bir bölümünün, sayıları giderek azalan dev şirketlerde yoğunlaşması durumu kapitalizmin eğilimlerinden olup özellikle geçtiğimiz yüzyılın başlarında hızlı bir biçimde yaşanmıştır (Hobsbawm 2013, s.197). Hobsbawm'ın (2013) "iktisadi yoğunlaşma" adını verdiği bu süreç son bulmuş değildir. Tüketim insanlıkla başlamakla beraber, yirminci yüzyılda farklı bir boyut kazanmıştır. Büyük Buhrana kadar uygulanan klasik iktisat politikalarının ve devletin uyguladığı para politikasının yeterli olmadığı sonucuna varılmıştır (Öncel, 1969). Üreticiler, yaşanan kriz dönemindeki küresel talep daralmaları ve yaşanan iki dünya savaşı yıllarında mallarını kendi iç piyasalarına yönelerek krizlerden korunma yoluna gitmişlerdir (Hobsbawm 2013, s.199-201). Büyük Buhran sonrasında fikirleri genel kabul görmüş Keynes'e göre yaşanan yoğun işsizlik ve istihdam daralmasının nedeni talep daralmasıdır. Tüketim eğiliminin artışı tam istihdam politikası için temel bir amaçtır (Rosanvallon 2004, s.44). Varılmakistenen sonuç ise; tüketimin üreti$\mathrm{mi}$, üretimin istihdamı artırması, böylelikle işsizliğin azalmasıdır.

Neredeyse tüm dünyanın etkilendiği II. Dünya Savaşı'nda özellikle sanayileşmesini tamamlamış ülkeler ağır kayıplar vermişlerdir. Savaşın bitmesinin ardından ülkelerin ekonomik durumuna bakıldığında Amerika'nın İngiltere, Fransa, İtalya, Almanya gibi ülkelerle kıyaslandığında önde olduğu görülmektedir (Hobsbawm 2013, s.234-249). 1945 yılına gelindiğinde Amerika, tarihin en büyük özgürlük dağıtıcılarından biridir. Zamanla Amerikan değerleri ve kültürü tüm dünyayı etkisi altına alabilecek hale gelmiştir (Lasn 2004, s.68). İhracatla zenginleşen ülke halkının buradan elde ettiği geliri tüketime harcayarak yaşam standartlarını artırması mümkün olmuştur.

1970'lerde yaşanmaya başlanan kriz, gerçekte kitlesel üretime dayalı sınai gelişme tarzının kriziydi. Otomobil, buzdolabı, fırın, çamaşır makinesi gibi kitlesel üretimin egemen olduğu ve gelişmenin motoru olan dayanıklı tüketim mallarına piyasa doymuş, geliri artan tüketici artık daha çeşitli mallar 
talep etmeye başlamıştı (Taymaz 1993, s.11). O yıllardan bu yana tüketimin ihtiyaçların giderilmesinden öte bir işlevi bulunmaktadır ve tüketim bu anlamda, kapitalizmin uygulamaları ile ideolojilerini meşrulaştırmak anlamında, belki de en öne çıkardığı faaliyet ya da çağrısıdır.

II. Dünya Savaşı'ndan sonra kurumsallaşarak yaygın bir birikim rejimi haline gelen sermaye birikim süreci, aynı zamanda yasal ve kurumsal düzeyde Keynesyen Refah Devleti ve bunun getirdiği düzenleme biçimleriyle somutluk kazanan Fordizm, 1970'li yıllarla beraber ciddi bir krize girmiştir. Fordizmin krizi, onun üzerinde şekillenen refah devletinin de krizi anlamına geldiği için, 1980 sonrasının devlet-ekonomi ilişkilerini değişime uğratmıştır. Yaşanan krize bir çözüm olarak uygulamaya konulan politikalar tüm ekonomik yapıyı ve toplumsal alanı değişime uğratmıştır. Neoliberal politikalarla serbest piyasa uygulamaları tekrar kapitalizmi destekler nitelikte olmuştur.

Özellikle son yüzyılda başlayıp günümüze değin devam eden süreç kapitalizmin hâkim üretim tarzı olmasına neden olmuş; değişen birikim rejimleri ve dolayısıyla farklılaşan tüketim yöntemleri, sermayenin gerekleri tarafından şekillendirilmiştir. Sermaye birikimi ve metaların değişim değeri temelinde biçimlenmek zorunda bırakılan tüketim, 1980 sonrasında yükselen birim düzeyine ve çeşitlenen metalara rağmen, toplumsal temelinden hayli uzaklaşmaktadır (Çetiner ve Erdal 2009, s.2). 1980 sonrasında küreselleşme olgusu ile de büyük bir ivme kazanan ve şekillenen kapitalizm ile tüketim ilişkisinin tarihi aslında bir hayli eskidir. On dokuzuncu yüzyılın ortalarından itibaren Amerikan kadınları tüketim için "dışarı çıkıp, satın almaya” özendirilmişlerdir. Ardından İngiltere ve Almanya'da benzer süreçler izlenmiştir. On dokuzuncu yüzyılın son yirmi yılına gelindiğinde; batı kapitalizminin büyük şehirlerinde çok katlı mağazalardan alışveriş etmek, orta sınıf kadını için evin dışında önemli bir etkinlik halini almış durumdadır (Bocock 1997, s.100). $\mathrm{Bu}$ anlamda tüketmek kapitalist toplumlarda hem bir gündelik pratik hem de yaşam tarzı biçimini almıştır.

İnsanların tüketmesi için mal ve hizmetler ülke sınırlarının ötesinden piyasalara sunulmaktadır. Dünyanın her yerinde müşterisi ve birimi bulunan işletmelerin sayısı artmaktadır. Küreselleşme, kutupsuz ya da tek kutuplu bir dünyayı anlatmak için kullanılan kavram değildir. Çok kutuplu emperyalist rekabette Amerika, Avrupa Birliği, Japonya gibi ülkelerde ticari değişimin yoğunlaşmasıyla beraber sermaye her geçen gün güçlenmektedir. Özellikle şaşırtıcı bir hızla küreselleşen finans kapitalden dolayı, egemen küreselleşmiş sermaye çoktan ortaya çıkmış bulunmaktadır (Öngen 1993, s.309). 
Günümüz toplumları için hafta sonu, geniş alışveriş merkezlerinde yiyecek, giyecek, kozmetik, mobilya, çamaşır, kitap satın almak, sinemaya gitmek ve en sonunda da akşam yemeğini yiyerek eve dönmekten oluşmaktadır. Bu yeni kapalı mekânlar, tüketicilerin içeride rahatça gezinebilmeleri, vitrindeki ürünlere göz gezdirebilmeleri gibi bir dizi imkânı da beraberinde getirmişlerdir. Böylece, rasyonel içerikli, satın alma davranışına, haz ve eğlenceye dayalı boş zaman eylemi de ilâve olunmuştur. Satın alma davranışı zorunluluk olmaktan uzaklaşarak, haz sağlayan, eğlenceli bir deneyim şekline bürünmüştür. Özellikle, günümüzdeki alışveriş merkezleri sunmuş oldukları çeşitli hizmetler ve gösterilerle alışverişin bu yeni anlamına uygun ortamlar içermektedirler (Özcan 2007, s.43). Söz konusu kamusal mekânlar ile aslında bireyler hem tüketmeye, hem de sosyalleşmeye davet edilmiştir. Bu anlamda tüketmek moda ve gerekli bir pratik olarak da görülmüştür.

Tüketimcilik, batılı ve diğer toplumsal oluşumlarda yaşayan milyonlarca kişinin günlük yaşamında ve günlük uygulamalarında kapitalizmi meşrulaştıran, sağlam bir kapitalizm ideolojisi haline gelmiştir (Bocock 1997, s.120). Kapitalizmin Fordist ve özellikle post-fordist döneminde, kitle iletişim araçları ile sunulan tüketim kültürü ve yaşam tarzlarının toplumsallaşma sürecine katkıları, kapitalizmin krizlerini aşmaya yardımcıdır (Dağtaş ve Dağtaş 2006, s.306). Kitle iletişim araçları sıkça vurgulandığı üzere tükettiren kapitalizmin ve tüketimciliğin yardımcısıdır. Çünkü “topluma egemen söylemlerin ortaya çıkmasında" önemli rol üstlenen kitle iletişim araçları bireylerin "tasarruftan hazcılığa yönelmelerine" adeta ön ayak olmaktadır (Ergur 2005'ten akt. Şahin 2009, s.126-127).

Tüketimcilik, yani yaşamın anlamının bir şeyler satın almak, önceden düzenlenmiş deneyimler yaşamak olduğunu öne süren etkin ideoloji, modern kapitalizmi egemenliği altına almıştır. Bu tüketim ideolojisi kapitalizmi meşrulaştırırken, insanları fantezilerinde olduğu kadar, gerçekte de tüketici olmak için güdülendirmeye yaramaktadır. Bunun da ötesinde yabancılaşmanın artışına hizmet etmektedir. Çünkü işyerinde bütün kademelerde çalışan işçilerin olası bir ekonomik durgunluk halinde işini kaybedecekleri korkusu yaşamalarına ve üretim yerine aidiyet duymamalarına yol açmaktadır (Bocock 1997, s.57). İnsanlar ev, araba, mobilya, kıyafet, yiyecek ve eğlence gibi birçok mal ve hizmeti satın alabilmenin umuduyla çalışmaktayken işsizler de alamamanın huzursuzluğundadırlar. Tüketim, yaşamı devam ettirme yolunda bir araç olmaktan çıkmış, kendi başına bir amaç halini almıştır. Sistemin içerisinde olabilmenin yolu, ancak sistemin üretmiş olduklarını tüketmekten geçmektedir. Metalaşan toplumda geleneksel değerler çözülmekte ve her şey 
adeta parasal değerlere indirgenmekte ve metalaşmaktadır. İnsanlar arasındaki ilişkiler, paranın başrolü oynadığı metalar aracılığıyla kurulan ticari ilişkilere dönüşmektedir (Özcan 2007, s.40). Bu anlamda kamusal alan kavramını kent sosyolojisi temelinde ele alan Sennett de (1996) Kamusal Insanın Çöküşü yapıtında kentlerin sunduğu yaşam tarzları ve bireyler arası ilişkileri salt bir alışveriş ilişkisine indirgemesi sebebiyle tüketimin bireyleri de tıpkı kendisi gibi anlamsızlaştırdığına vurgu yapmaktadır.

Tüm bu tüketim çılgınlığının sonucu, gelişmiş ülke insanları ve çeşitli biçimlerde tüketmeye özendirilen gelişmemiş ülke insanları için farkl1dır. Elde edilen gelirin yapılan harcamadan daha az olması baş edilemeyen borçlara neden olabilmektedir. Tüketici kredileri ve kredi kartları gibi bazı tüketim kolaylıkları ülkemizde 1990'lı yıllar ve sonrasında dikkat çekici boyutlara varmıştır. Kapitalizmin aşamalarından biri olan üretim kalıplarının ve pazarlama faaliyetleri aracılığıyla gündelik yaşamımızın hızla dönüşmesi eşzamanlı olmuştur. Sonuç olarak; çok tüketerek kendini yeniden ürettiğini düşünen insanlar yaratılmıştır (Çetiner ve Erdal 2009, s.13). Söz konusu kimseler için tüketmek bir yaşam tarzı ya da gündelik bir ritüel halini almıştır. Örneğin bireyler nakit paraları olmasa dahi kredi kartı aracılığı ile tüketime teşvik edilmektedir. Günümüzde yaygın bir varsayımdır ki, kredi kartının cepten nakit para çıkmadan alışverişe olanak tanıması bireylere ürünlere hiçbir ücret ödemeden sahip olma hissi verirken, tüketimin bir çılgınlık ve gündelik bir ritüel halini almasına da neden olmaktadır. Gelir düzeyi düşük olan alt sınıftan bireyler kendilerini orta sınıfın tüketim alışkanlıklarına ayak uydurmak zorunda hissetmekte, alışveriş merkezleri aracılığı ile tüketmekten haz almaktadır. Modern zamanlar ile birlikte oluşan, zamanını nitelikli biçimde kullanmayan ve Veblen'in "aylak sınıf" biçiminde nitelediği sınıf, tüketimin modernliğin bir parçası olduğu iddiasının bir göstergesidir. Bu sınıf "gösterişçi tüketim" aşkı ile modaya uymak ya da başkalarının sahip olmadığı şeyleri alabilmek için para harcamakta ve yine başkalarını kıskandırmak veya birilerinin gözünde saygı kazanmak adına "tüketmektedir" (Veblen 2005'ten akt. Hürmeriç ve Baban, 2012, s.92). Bu anlamda bireyler tüketim kültürü içerisindeki tüketim pratiğini bir statü göstergesi biçiminde yorumlamaktadır (Kaya ve Oğuz 2010, s. 147). Simmel'e göre (1996) ise, bireyler modern dünya içerisinde tüketmek sureti ile var olmaktadır. Tüketme bilinci yaratan metropoller "bütün kişisel yaşam aleyhine büyüyen bu kültürün gerçek alanını" nitelemekte ve yapay kimlikler yaratmak sureti ile bireylerde "farklı olma" arzusu uyandırmaktadır. Tüketmeyi de bir farklı olma biçimi olarak gören insan, tüketerek var olmakta ve "öznel ruhunu" doyurmaktadır. 
Aydoğan'a göre (2009, s.213), Türk insanı da hafta sonlarını ya "AVM'lerdeki tüketim ürünlerini izleyerek" ya da "kredi kartı taksitlendirmesi vasıtası ile söz konusu ürün ve hizmetleri "sahiplenerek geçirmekte" ve böylelikle tüketim kültürünün bir parçası olmaktadır. Üniversite gençliğinin tüketim alışkanlıkları bağlamında ise moda, alışveriş merkezleri ve reklamların etkisinin büyük olduğu göze çarpmaktadır (Kaya ve Oğuz 2010, s.154-162).

Gündelik yaşam içerisinde tüketimin finansmanını sağlayan bazı gelişmeler olmuştur. Emek kesiminin ücretlerini banka kanalıyla alması, müşteriyi finans kesiminin ayağına getirip kendine bağlamasını kolaylaştırmıştır. İstihdamın kayıt altına alınması adına emekçilerin ücretlerinin banka kanalıyla ödenmesi, insanların mevcut gelirlerinin üzerinde harcama yaparak gelecekte alacakları geliri şimdiden tüketmelerini kolaylaştırmaktadır. Yöntem zorda kalındığında ihtiyaçların borçlanarak sürdürülebilmesine imkân sağlar. Finansal kesimin borçlanmanın kolaylığı karşısında, ödenmeme riskine karşı iki farklı çözümü bulunmaktadır: Birincisi; yüksek faiz oranı uygulamaları, ikincisi; hukuksal anlamda güçlü avukat kadrolarıdır (Çetiner ve Erdal 2009, s.13). Ancak finansal kesimle bireyler arasındaki bu hukuksal mücadele süreci çoğunlukla tüketicilerin kaybetmesiyle sonlanmaktadır.

Tüketmek aşırı borçlanma dışında bazı toplumsal sıkıntılara da neden olabilmektedir. Örneğin; çoğu Amerikalı her istediği mal ve hizmete sahip olmasına rağmen bunlarla yetinmeyi aklına bile getirmez. Her şey elimizin altındayken hiçbir şey mücadele ile kazanılmış olmaz; mücadeleyle kazanılmayan hiçbir şey kişiyi tatmin etmez. Tatminsizlik yaşamımızı sı̆̆ ve anlamsız kılar. Her şeyin devleştiği çağımızda, "az" görünen yaşamları telafi etmek amacıyla sürekli “daha çok"un peşine düşülmektedir (Lasn 2004, s.11). Dolayısıyla refah seviyesi artan toplum eksik kalan bu yönüyle mutsuz olabilecektir. Bu bağlamda tüketim ve sosyo-ekonomik durum arasındaki ilişki, tüketimciliğin düzeyi ve toplumsal boyutu içinde bir belirleyici niteliğindedir.

\section{Tüketme ihtiyacını ortaya çıkaran etmenler}

Batılı kapitalist toplumsal oluşumlar, ekonomik durgunluğun yaşanmadığı yıllarda tüketim mal ve deneyimlerini satın alabilecek güçtedirler. Tüketicilik kültürünün çekiciliğine gittikçe daha fazla kapılan ve nüfusun üçte ikisi ile dörtte üçü kadar bir bölümünü oluşturan bir insan çoğunluğuna sahip olan kapitalist oluşumlar, geniş kitleleri kapsamaktadır. Bunun anlamı, daha çok reklâm ya da televizyon programlarında izlediklerinin sonucu olarak arzu ettikleri ve zevk alacakları tüm deneyimleri karşılamaya ekonomik güçleri yetmese de, birçok insanın alıcı ya da tüketici olmayı istemeye devam etti- 
ğidir (Bocock 1997, s.83). Yaşadığımız evreni dâhil etmeksizin düşünebilmeyi başararak, ihtiyaçlarımıza ya da başka bir şeye karar vermek çoğu zaman mümkün olamamaktadır.

Toplumsal kabulün ortak değerler algısına artık ulaşmak istediklerimiz için harcadığımız emek değil, harcanılmayan emek yeğ tutulmaktadır. Sahip olmak için çalıştıklarımıza sahip olduğumuzda değerini kaybetmektedir. Tüketimcilik bir davranış biçimi olmaktan çok, bir değer, yaşam tarzı, hayatın asli gayesi ve ölçüsü haline gelmektedir (Aytaç 2002, s.124). Tüm alınmak istenenler ise, birer ihtiyaç biçiminde sunulmaktadır. Böylelikle zihinsel bir aldatmacayla, pazarlama yapılmaktadır. Teknolojik gelişme ve reklâmlar ile ivme kazanan ekonomik iktidar sahipleri, gündelik hayatın her alanında bugün insanları denetlemek ve kontrol etmek konusunda Panoptikon'unu kurmaktadır (Şentürk 2008, s.238). Bu bağlamda da tüketim olgusu, bireyleri etkileme gücüne paralel bir biçimde kitle iletişim araçlarına büyük görevler yüklemektedir. Hegemonik yaşam tarzı içerisinden sıyrılamayan bilinç, düşündüklerini de bu hegemonyanın tesiriyle düşünmekte olduğunu bilmeksizin özgür zihni ve özgür davranış kalıplarıyla mutluluğun yollarını aramaktadır. Yaşam tarzımız ve mutlu dünya algımız özellikle kitle iletişim araçlarının yönlendirmesi ile tüketmek üzerine kuruludur ve benzer kalıplar etrafında dönmektedir. Mutsuz olmamız da mutlu olmamız kadar kısa süreli ve yakın kavramlar olduğundan ruh halimiz düzelememektedir.

\section{Medyanın etkisi}

Medyanın kapitalizmi temel alan içerikleri ile bir tüketim toplumu yarattığı iddiası hararetli bir tartışma olarak uzun süredir ortadadır. Söz konusu iddialara göre medya, içerikleri ile kapitalist düzende var olan tüketimi hızlandırmakta ve bireyleri tüketime yönlendirmektedir. Chomsky'nin (2012) medyanın kimi zaman mevcut düzenin çıkar ve pratiklerine hizmet ettiği görüşünden yola çıkarak mevcut kapitalist düzen içerisinde tüketim kültürünün de söz konusu çıkar ve pratiklerden biri olduğunu söylemek yanlış olmayabilir. Çünkü medya popüler kültürün kapitalist ürün ve içeriklerini tanıtır, meşrulaştırır ve kanıksatır. Böylece medyada görülen/gösterilen her bir nesne ya da durum kapitalist tüketim sürecinin emtiaları olarak düşünülebilir. Reklâmlardan popüler kültür ürünü olan dizilere kadar birçok şeyin bireyleri tüketime teşvik ettiği söylenebilir. O halde "medya başlı başına bir endüstri" konumuna sahiptir (Yaylagül, 2006). Frankfurt Okulu'nun temsilcileri olan ve kitle toplumu, kültür endüstrisi ve tüketim toplumu üzerine düşünen Horkheimer, Adorno, Marcuse ve Lowenthal kapitalist sistem içerisinde (Kellner 
1989'dan akt. Şan ve Hira, 2011, s.6-7) kültür ve tüketimin toplum üzerine etkilerini tartışmış ve önemli görüşler ortaya atmıştır. Bunu yaparken de kültür endüstrisi ve tüketim kültürü temelinde kitle iletişim araçlarına da büyük önem atfetmişlerdir.

"Modern totaliterliğin" temelinde (Şan ve Hira 2011, s.6-7) kitle kültürü ve kültür endüstrisinin olduğunu söyleyen Adorno ve Horkheimer, kültür endüstrisinin "kitleler ile olan ilişkisini kötüye kullanarak, verili ve değişmez sayılan bir zihniyeti çoğaltmaya ve güçlendirmeye çalıştığına" dikkat çekmektedir (Adorno, 2003). Marcuse ise kültür endüstrisi ve endüstri toplumu bağlamında kitle toplumu ve pratiklerini ele almaktadır. Ona göre modern toplumda çalışmak "tüketici, sersemletici ve sıra dışı bir kölelik" halini almıştır ve sıradan bir bireyin etrafı sahte ihtiyaçlar ile çevrelenmiştir (Swingewood, 1996'dan akt. Şan ve Hira, 2011, s.6-7). Marcuse (1997, s.6-7) kapitalist düzende yaratılan tek boyutlu insanın sahte, yapay tüketime yönlendirildiğini söylerken, "toplumsal denetimlerin savurganlığın üretim ve tüketimi için ezici gereksinimi zorunlu tuttuklarına" da dikkat çeker. Marcuse'ye göre (1997, s.6-7), kitle toplumu içerisinde gerçek zorunlulukların mevcut olmadığı yerlerde yaratılan zorunluluklar vardır ve kendini denetim altına alan "özgür basın, markalar ve ıvır zıvır arasında özgür seçim gibi aldatıcı özgürlükleri sürdürme için gereksinimi zorunlu kılmaktadırlar." Ayrıca Marcuse, kitle toplumunda var olan farklı yüksek kültür ile alt kesimlerin kültürünün de eskide kaldığına dikkat çekmiş ve kitle kültürü sanatının yani tek boyutlu sanatın içerisinde klasik sanatın "en olumsuz" örneklerinin dahi kaybolduğunu ifade etmiştir (Sevim 2010, s.510). Bu kayboluşta kuşkusuz mevcut kültür unsurlarının yerine kültür endüstrisi metalarını koyan kitle iletişim araçlarının rolü yadsinamaz ölçüde büyüktür.

Kitle iletişim araçlarının meşrulaştırdığı bir kültür türü olan ve küreselleşme olgusu ile bir ivme kazanan popüler kültür de, birçok içeriği ile tüketim kültürünün oluşmasına hizmet etmektedir. Popüler kültür aslında küresel kültürü kitlesel bir forma dönüştürür ve beraberinde popüler emtiaların tüketilmesi ile tüketim kültürünün önünü açar.

Tüketim kültürü en net ifade ile modern kapitalist toplumlarda mal ve hizmetlerin pazarlanmasını ifade etmektedir ve söz konusu mal ile ürünlerin tüketimine doğru gidişin kültürel anlamda egemen bir hal almasıdır. Toplumların modern anlamda statü bağlamında farklılaşmak sureti ile pazar bakımından da bölünmüş bir hal almasını niteleyen tüketim kültürü, tüketicilerin yani bireylerin toplumsal değerleri kişisel yaşam biçimlerini de yan- 
sitır (Mutlu 2004, s.286). Aslında kitlesel tüketimin bir eleştirisi niteliğinde olan tüketim kültürü, kapitalizmin toplumları tüketime doğru teşvik etmesi ile oluşan maddi ve manevi bir alışveriş ve etkileşim kültürünü niteler. Tüketim kültürü reklâmlar, popüler kültür ürün ve içerikleri ile bireylere sunulur ve zaman içerisinde tüketimde bir artış hedeflenir. Destinasyon pazarlaması bağlamında tüketimin en büyük yardımcısı olan reklâmlar göstermek sureti ile tükettirir.

Debord'a göre (2014), reklâm tüketim zamanına işaret eder ve insanlar reklâmları izleyerek evlerinde oturdukları yerden küresel emtiaları tüketir. Ona göre, reklâmlar medya gösterisinin bir boyutudur (Debord, 2014) ve tıpkı gösteriden kaçmanın imkânsız olduğu gibi reklâmlardan kaçmak da imkânsızdır. Çünkü hem maddi hem de manevi tüketime teşvik eden reklâmlar sokaklardaki billboardlardan tüm televizyon kanallarına kadar her yeri adeta baştan sona donatmış durumdadır. Fiske'ye göre de, reklâmlar aslında ürünü değil, tüketimciliği satar (Fiske 2012, s.45). Buradan bakıldığında tüketim olgusu içerisinde kitle iletişim araçlarının tüm içerik ve uygulamalarının büyük rol oynadığı görülür.

Adorno da tüketim ile oluşturulmuş tüketici kültürünün aslında kültürün yozlaşması olduğunu söyler. Ona göre; kültür endüstrisi “tüketicinin tepeden ve kasten birleştirilmesidir" (Adorno, 2007) ve tüketim kültürü ile de tüketim temelinde bir birleştirme ve yöndeşme yaratılmaktadır. Yalnız maddi ürün ya da olgular değil, manevi ürün ve olgular da tükettirilmektedir. Aslında Bauman ve Lyon'un Akışkan Gözetim (2013) isimli yapıtlarında söyledikleri gibi; "gönüllü bir şekilde tüketime de tıpkı gözetim gibi iştirak ediyor ve tüketimi doğallaştırıyoruz". Gönüllü tüketime nasıl ki iştirak ediyor ve tüketimi doğallaştırıyorsak, gözetim de "kamusal alanların itirazsız parçası"dır. Tüketim de gündelik yaşam pratiklerinin vazgeçilmez bir parçası olarak var oluyor ve özellikle medya tarafından cazip hale getirilmek sureti ile doğallaştırılıyor (Baumann ve Lyon, 2013). Bu anlamda günümüzde medya, göstergelerin ve sembollerin tüketilmesine yönelik önde bir role soyunmuş olup, sunulan ürünlerin gerçek işlevlerinden çok, toplumsal bir işlev taşıyor gibi gözükmesine ve bir simülasyon içinde gösterilmesine yol açmaktadır (Baudrillard, 2003). Baudrillard'a göre (2000, s.11), birçok şey artık kendi kendine kaybolmamakta, simülasyonların gerçek olanın yerini alması ile yok olmaktadır. Dolayısı ile artık gerçeklik olgusu kaybolmuştur. Baudrillard'a göre (2003, s.15) gerçek artık kaybolmuştur ve "bir daha asla geri dönmeyecektir." Bireyler artık "her türlü düşsel ve gerçek ayrımından yoksun, yalnızca aynı 
yörünge çevresinde dolanan modellere dayalı ve farklılık simülasyonu üretiminden ibaret bir hipergerçek" ile karşı karşıyadır ve "gerçeği, hipergerçeğe dönüştürme" bağlamında en önemli araç medyadır. Öyle ki ona göre, medya gerçeği hipergerçeğe dönüştüren genetik bir kod niteliğindedir (Baudrillard 2003, s.57). Bu noktada Thompson da Medya ve Modernite isimli yapitında sıkça modern toplumun şekillenmesinde medyanın oynadığı role dikkat çekmektedir (Thompson, 2008). Çünkü modern dünyada medya iletileri geçmişten bugüne aktif bir biçimde bireyin benliğine şekil vermektedir.

Medya içeriklerinde üretilen mal ve hizmetlerin çok çeşitliliği ve bireye yönelik farklılı̆̆ ya da yeni bir benliği getirmeleri karşısında seçim yapmak imkânsız hale getirilmekte, böylece seçkin bir yaşam tarzı vurgulanmaktadır (Dağtaş ve Dağtaş 2006, s.2). Yeni egemenlik tarzının ayırt edici özelliği; bastırmanın yerine baştan çıkarmayı, zorla düzenlemek yerine halkla ilişkileri, otorite yerine reklâmcılığı, kurallar dayatmanın yerine gereksinim yaratmayı geçirmiş olmasıdır. Bireyleri bugün topluma bağlayan şey, onların birer tüketici olarak etkinlikleri, tüketimin etrafında dönerek harcadıkları yaşamlarıdır (Şan ve Hira 2004, s.19). İşte bu yüzden tüketim olgusu gündelik yaşamda hem bir ritüel hem de bir sosyalleşme pratiği halini almıştır. Tüketim olgusu, tüketici bireyin kullandığı eşya, bitirdiği yiyecek ve içeceklerin karşılanması olarak, zaman içinde değişerek olgunlaşmıştır. Her ekonomik sistemin, sosyal yapının, kültürel düzeyin veya genel anlamda bakarsak toplumun tüketim usulü farklı olabilmektedir. Bunların dışında zaman içerisinde değişebilmekte, değiştirilebilmektedir. Değişimin öncüsü; üretim yapanlar, tüketici beklentileri, hükümetler, devlet sistemleri, inançlar gibi pek çok şey olabilir.

Kitle iletişim araçları ile dolayımlanan tüketim kültürü, yaşam tarzlarının toplumsallaşma sürecine etkisi, hazza dayalı ve bencil bireyselliğin inşasına katkıda bulunarak gerçekleşmektedir. Bu durum geleneksel toplumun çözülmeye başladığı kapitalizmin başlangıcından, bugüne kadar böyle devam etmiştir (Dağtaş ve Dağtaş 2007, s.2). Kapitalizm neredeyse her dönem kitle iletişim araçlarının etkinliğinin bilincinde olup onu en çok da tüketim noktasında bir argüman olarak kullanmıştır.

Dünyada, tüketim arzularının, kitle iletişim araçları ve modern reklâmcılık aracılığıyla dürtülenmesi, oluşturulması ve anlatıma kavuşturulması sonucu kendisine sunulan malları fark eden grupların sayısı gibi, kimlik ve yaşam hedefini "tüketim" aracıllğıyla oluşturan kişilerin sayısı da artmaktadır. Tüketim, kimlik elde etmek isteyen bu kesimler için iyi bir alternatif oluşturabilir (Bocock 1997, s.115). Birey, tükettiği ürün ve hizmetler üzerin- 
den sosyo-ekonomik ve kültürel kimliğini konumlandırabilecektir. Ülkemizde 1980 sonrası liberal ekonomi uygulamasının toplumsal, kültürel ve entellektüel hayatımızda yarattığı değişim sonrasında yeni elitler ortaya çıkmış ve bu da burjuvazide bir kabuk değişimine neden olmuştur. Dönüşen seçkin anlayışı, Amerika hayranlığı, tüketimi methetme ve halkı küçümseme gibi eğilimleri dışa vuran bir medya anlayışına neden olmuştur (Bali 2002, s.14). Rezidanslar ikamet etmek için tercih edilmeye başlanmış; eğlence mekânları Pera'dan Ortaköy, Cihangir ve Galata'ya yer değiştirmiş; şarap, puro içmek, cep telefonu kullanmak zenginlik ve lüksün simgesi olmuş; Amerika'da eğitim almak, orada bulunmak ve yaşamak elit olmanın gereklerinden kabul edilmeye başlanmıştır (Bali, 2002).

Çeşitli teknikler kullanarak insanların kazançlarının büyük bir kısmını tüketime ayırması için birçok taktik denenmiştir. İnsanları yönetebilmek ve arzu edilen davranışı gerçekleştirmesini sağlamak için psikoloji, sosyal psikoloji, sosyoloji, müzik, resim gibi birçok bilim ve sanat alanından faydalanılmaktadır. Alışveriş için girdiğimiz alanlarda kullanılan müziğin tarzı ve ritmi bizi satın alma davranışına yönlendirebilecekse çalınmaktadır. Kullanılan reklâm panolarındaki ürün ve hizmetlerin kendileri yanında renklerinin de zihnimizde ifade ettikleri anlamları ve çağrışımları, artık kapitalizmin kendi yanına aldıkları materyaller olmuşlardır. Doğadaki renkler, figürler, ritimler, sesler ve daha pek çok şey satın alma davranışını kontrol etsin diye var olmadıkları halde bunun için kullanılmaktadırlar. Toplum içerisindeki bizleri tüketim deliliğine sürükleyen neden; bolluğun laneti, imaj patlaması, aşırı bilgi yüklemesi, her daim iş başında ve uyanık medyanın bombardımanının toplamı olabilmektedir. Medya bağımlısı, tüketim odaklı kültür bizi her şeyden çok hasta edendir (Bocock 1997, s.12). Yaşadığımız her yerde ticari amacı olan görsel ve işitsel materyallere rastlamamız kaçınılmazdır.

\section{Kimlik ve statüye sahip olma arzusu}

Maddi ve toplumsal ihtiyaçların kapitalist düzen tarafından belirlendiğini düşünen Marx (1993), günümüzde hayatta olsaydı muhtemelen söz konusu ihtiyaçların karşılanmasından önce nasıl yaratıldı̆̆ı üzerine kafa yorardı, çünkü bugünün postmodern ve kapitalist dünyası içerisinde bireylerin tüm ihtiyaç ve pratikleri yine kapitalizm temelinde belirlenmekte ve küresel bir talep modası yaratılmaktadir.

Sürekli yeni mal edinmenin nedeni Featherstone'a göre; modaya uygun arzu edilen malların arz edilmesi ya da statü işareti olan malların alt katmanlardaki gruplar tarafından gasp edilmesi, en üsttekilerin önceki toplumsal 
mesafeyi yeniden tesis edebilmek için yeni (enformasyonel) mallara yatırım yapmak zorunda kalmalarıdır. Bu bağlamda bilgi, yeni malların sosyo-kültürel değeri ve bunların uygun bir usulde kullanımıyla önem kazanır. Tüketim ve hayat tarzının yeşertilmesi konularında bilgilenmeye meraklı, gözü yukarılarda olan gruplarda durum özellikle böyledir (Featherstone 1996, s.45). Buradan anlaşılmaktadır ki, toplumun bir kesimi kendileri ve ötekileştirdikleri diğerleri hakkında ayrı sosyal, ekonomik ve kültürel temelli olabilecek statü düzeyi tanımlamaktadırlar. Bulundukları statü basamağında çeşitli mal ve hizmetleri kullanarak kimlik kazanmaktadırlar. Farklı kimlik bilincinde olan gruplar algı, düşünce ve davranış biçimlerinde de ayrışmaktadırlar.

Tüketim kültürü içerisinde kültürün toplumsal hayatın merkezine taŞınması eğilimi vardır, ama bu kültür başat bir ideoloji gibi bir şeyler oluşturacak şekilde tutunum edinemeyen bölük pörçük ve sürekli yeniden işlenen bir kültürdür. Kültürü, gündelik pratiklerde nasıl kullanıldıklarını, üretim ve neşirleriyle kimlerin uğraştığını sormaksızın gösterge ve imge sistemleri düzeyinde ele almaktan elbette kaçınmak gerekmektedir (Featherstone 1996, s. 189). Böylelikle ancak oluşturulan bütünü görmek mümkün olabilir.

\section{Tüketim ve postmodernizm}

Günümüzün en müphem ve tartışmalı kavramlarından biri olan ve modernizmin ötesi biçiminde ifade edilen postmodernizm, Jameson'a göre (1991, s.1-15) "gerekli bir moda" ve "modernizmin paradokslarına bir cevap" niteliğindedir. Ecevit ise (2000, s.59) postmodernizmi, "mutlak doğrular ve kesin değerlerin tek başlılığına yer vermeyen bir ortam" olarak tanımlar. Postmodernizmin sosyolojinin ilgilendiği bir konu olmasını sağlayan kişi olan Lyotard (2013) ise, gelişmiş toplumlarda bilginin durumunu ortaya koymayı amaçlar ve bunu yaparken Postmodern Durum isimli eserinde postmoderniteyi "bir bilgi biçimi" olarak yorumlar. Jameson ve Lyotard'dan farklı olarak Stevenson ise (2008, s.241) postmodernizmin "toplumsal antagonizma biçimlerini sonlandırmayı vaat eden bir yaklaşımlar bütünü” olduğunu söyler.

Iggers'ın "sınai büyümeye, yükselen ekonomik beklentilere ve geleneksel orta sınıf kurallarına ilişkin eski kabullerin sarsıldığı, dönüşüm halindeki bir toplumu ve kültürü yansıtır" (Iggers 2000, s.14) ifadesi ile tanımladı̆̆ı postmodernizm, modernizmin üretim ve tüketim ilişkilerine karşı bir duruş sergilerken varlığı ile küresel bir tüketime işaret eder aslında. Modernizm modern dünya içerisinde nasıl hep bir tutarlılık peşinde ise (Özbek 2005, s.8), postmodernizm de hep bir çeşitlilik peşindedir. Çünkü postmodernizm sav- 
ları ile modernizmin temeli olan Batı metafiziğine ve modernizmin mutlakiyetçi anlayışına bir savaş açarken, çeşitliliği savunur ve bu noktada çeşitlilik ve üretmek için tüketimin de önünü açar.

Bulunmaz, postmodern dünyanın insanları farklılaştırdı̆̆ını, yalnızlaştırıp yabancılaştırdığını söyler (2013, s.13). Bulunmaz'a göre, bu durumda teknolojinin de payı büyüktür. Çünkü teknoloji bireyleri birbirine yaklaştırırken, aslında onları birbirine yabancı insanlara dönüştürmekte ve postmodernizm de aslında tüketime teşvik etmektedir.

Postmodernizmin merkezine oturan bu tüketim endüstrisi, toplumun her bir düzeyi için ayrı önerilerde bulunurken, insanların çalışma dışındaki boş zamanını nasıl geçirmeleri gerektiğine dair yeni alternatifler sunmaktaydılar. Dinlenebilmenin çeşitli alternatifleri içerisinde tüketime dayalı aktiviteler bulunmakta, işten arta kalan zamanlar artı değer oluşturması için tüketime yönlendirilmekteydi (Aytaç 2004, s.234). Nihayetinde çalışanlar işte üreterek, boş zamanlarında ise bu faaliyetin aksini gerçekleştirerek yani tüketerek zamanlarını geçirmekteydiler. Postmodern tüketimcilikte arzu duyulan şey, tüketilen "gerçek" çikolata, "gerçek" otomobil, ev veya mobilya değildir. Asılında bu "gerçek" nesneler, arzuların yerine konan şeylerdir; doyurulması istenen arzular, sembolik arzular olup, kültürel sembolizm tarafından doyumlanmadan, biyolojik olarak sahip olunan arzular değillerdir (Bocock 1997, s.118). İnsan arzuları mal ya da hizmete değil, içsel faktörlere ait olduklarına göre; tüketilmek üzere alınmış nesnenin kişiye ait olması, onun bir başkasını istemeyeceği anlamına gelmeyecektir. O yüzdendir ki; peşinden koşulan mal ve hizmetlerin değeri, alındığında eskiyebilmekte ve yenisi istenebilmektedir. Sadece mal ve hizmetler için değil aşklar için de geçerli olan bu durum sonucunda, elde edilen sevgilinin ardından bir başkasına zaman kaybetmeden gidilebilmektedir. Bu nedenle evlilikler kısa sürmekte, uğruna birçok şeyin feda edilmiş olduğu aşklar çok çabuk eskimektedir. Günümüzde aşk bile bir tüketim objesi halini almış durumdadır. Evrilen tüketim alışkanlıkları ve değişen yaşam tarzları çerçevesinde bireyler sıkça partner değiştirebilmekte, aşkı tüketirken aslında karşı cinse ilişkin algı, beklenti, heyecan ve saygı gibi nitelikler ve arzuları da tüketmektedir. Bunun bir sonucu olarak da sürekli arzulayan birey doyumsuzluğa davetiye çıkarabilmektedir. Bu noktada tüketimin önemli argümanlarından olan "arzu" kavramı ile bir sevgi biçimi olan "aşk" kavramı arasında bir ayrıma giden Baumann'a göre, (2009, s.18-20) arzu tüketmeyi, aşk ise benliğin hayatta kalmasını amaçlamaktadır ve bu yüzden arzu tükenirken, aşk sürebilmektedir. Öyle ise bireyin aşk ile tükettiği aslında 
beklenti, saygı ya da heyecanı değil, arzusudur. Zaten biçimi ne olursa olsun tüketimciliğin hedeflediği de budur: Arzu ettirmek sureti ile tüketmek!

Postmodern süreçte tüketim noktasında "alışverişe gitme" pratiği de kuşkusuz büyük önem taşımaktadır. Alışverişe gitme, belirsiz, savurgan, sözel olarak gezinmeye yönelik bir eylemdir. Sonu açıktır, kesin bir yer ya da plandan yoksundur. Sadece bakınmayı ve hiçbir şey satın almamayı içerebilir. Alışverişe gitmek, haz vericidir ve ölçüsüzdür; çok fazla zaman ya da para harcamayı gerektirebilir. Alışveriş yapmak ise, bir mecburiyeti ya da rutini çağrıştırmaktadır. Dolayısıyla alışveriş, hem planlı ve hem de sınırlı bir eyleme gönderme yapmaktadır; tanımlanmış bir nesne söz konusudur, sapma ya da fazladan bir şey satın alma yoktur. Alışverişe gitme modaya, kıyafetlere, boş zamana işaret ederken, alışveriş yapmak ise, yiyecek alışverişine ve daha ziyade bir görevin parçasına gönderme yapmaktadır (Özcan 2007, s.50). Boş zamanımızı harcamak için gittiğimiz yerleri, tüketim yerlerinden ayırmak neredeyse imkânsız hale gelmiştir. Yani boş zaman, harcama yapmak için kullanılan bir süre olarak kullanılmaktadır. Alışveriş için gidilen yerler, tüketmeye yönelik sosyalleşme mekânları olmuşlardır.

Tüketim noktasında alışverişin bir neticesi olarak bireylerin satın aldıkları mal ve hizmetlerle kimi zaman kimlik ya da statü sahibi olunabilirken, kimi zaman ise alınan mal ve hizmet farkında olmadan kişinin kimliğini ele vermektedir. İnsanlar, ürünün tüketilmesi esnasında arzu ve isteklerinin özelliklerini belirtmek ya da iletişimde bulunmak isterler ki, bu, ürünün sembolik yönüdür. Belki buna "uzatılmış benlik" ya da "sembolik benlik tamamlama" denilmektedir. Bu özellikler, bireyin sahip olmak istediği ya da sahip olduğu belli özellikler hakkında ipuçları verebilmektedir. Ne tükettiğine göre, kim olunduğunu belirlemektedir. Ürün ve hizmetler, sembolik olarak tüketicinin bu ürünler aracılığı ile ne olabileceğini gösterdiği gibi onlarsız ne olmayacağını da belirler (Belk, 1988). Yani tüketim tüketimi artırdığı gibi, tüketim alışkanlıklarını da değiştirebilmektedir.

Tüketim noktasında kültürün ekonomiyi etkilediğine çoğunlukla yer verilmemesine rağmen, postmodern açıklamalarda ona yön verdiği göze çarpmaktadır. Ekonomi ve kültür ilişkisinin karmaşıklığı ve değişimi yeni olguların oluşmasında ve postmodern tüketicinin varlığının belirlenmesinde etkin rol oynamaktadır. Modern ve postmodern düzenlerin üretim biçimleri olan fordizm ve post-fordizm uygulamaları, tüketim kültürü ve postmodern tüketicinin özelliklerinin anlaşılmasında bizlere yardımcı olabilmektedir. Yeni tür tüketicinin daha aktif, kendisini gerçekleştiren ve yaratıcı bir rol benimse- 
mesi, sosyo-kültürel kimliğinin ürün ve marka seçiminde daha baskın olacağını göstermektedir. Sadece ürünün fiziksel, işlevsel özelliklerinin değil, onun taşıdığı ve gösterdiği imajları daha çok önemseyen postmodern tüketici, hiç şüphesiz yeni bir ekonomi ve yeni bir kültür oluşumunun içinde yer almaktadır (Odabaşı 2004, s.104). Böylelikle, toplumsal gelişmeler nedeniyle kimliksizleşen postmodern dönem insanının, seçimleriyle birey olabilme isteğine cevap vermeye çalışmaktadır.

Postmodernizmin, tüketicisini yoran, şoklar yaratan bir tarzı vardır. Teklik değil çeşitlilik, genel değil özel, alışılmış değil sıra dışı çekici gelmektedir. Nesnel olmaktan çok göreceli olanı, objektif olma yerine duygu ve sezgiyi kullanmayı yeğler, seçici, titiz, kuralcı değildir. Eğitici, öğretici olduğu kadar da, modernizmin mantıksal kurallarından, sıkıcı atmosferinden kurtularak rahat soluk alma, tek düzeliğe dönüşmüş yaşamı yeniden yorumlama, modern zamanın insanlara bellettiği sınırları yok ederek, günümüzün sıkıntılı bunalımlı insanlarına bir çıkış yolu bulma arayışındadır (Özbek 2005, s.16). Günümüzün stresli iş ve yaşam koşulları arasında gidip-gelen insan için tüketim, sorunlarından bir müddet de olsa uzaklaşma ve rahatlama yoludur.

Tüketici olan, modern yurttaş için yeni etikte geleneksel çalışma ve üretim zorlamasının eşdeğerlisi olan bu mutluluk ve haz zorlamasının elinden kaçıp kurtulmak mümkün değildir. Modern insan hayatını giderek daha az emek içinde üretimle ama giderek daha fazla kendi ihtiyaçlarının ve refahının üretimi ve sürekli yenilenmesiyle geçirir. Modern insan tüketimci potansiyelliklerinin ve kapasitelerinin tamamını seferber edecek şekilde kendisini hazırlamak zorundadır. Eğer bunu unutursa, kendisine mutlu olmama hakkına sahip olmadığı kibarca ve israrla hatırlatılır. Dolayısıyla modern insanın edilgin olduğu doğru değildir: Modern insanın sergilediği ve sergilemek zorunda olduğu sürekli bir etkinliktir. Aksi halde modern insan sahip olduğuyla yetinmek ve toplumdışı olmak tehlikesi ile karşı karşıya kalacaktır (Baudrillard 2004, s.94). Bu yüzden tüketim sürekli olması gereken bir zorunluluk halini almıştır.

Ekonominin düşüşe geçtiği bunalım ve durgunluk dönemlerinde bile tüketim insanlar için bir ümit olması açısından önemini korumaya devam eder. İşsiz kalan kişiler bunalım içindedirler, ama bunun sebebi yalnızca bir çalışan olarak değerlilik duygularının ortadan kalkması değil, aynı zamanda ailesinin gereksinimlerini gideren, her türlü tüketim malını sağlayan kişi olarak da rollerinin kaybolmuş olmasıdır. Böyle deneyimler sonucunda kimlik değişir, parçalanır, yeniden oluşur. Postmodern anlamda tüketememek derin 
bir hoşnutsuzluk haline gelir (Bocock 1997, s.114). İnsanın iş dışındaki zamanını işe yeniden hazırlanmak ve rahatlamak için kullanması gerekirken, kapitalist üretim tarzı ve ilişkileriyle ters düşmeyen oyunun, dinlenmenin ve eğlencenin ürettiği dünyada geçirmesi gerekmektedir. Kendi kimliğini gerçekleştirmekte zorlanan insan üretim tarzının getirdiği materyal ve bilişsel egemenlik altında biçimlenmiş kendiyle yabancılaşabilmektedir. Öyleyse ne işte ne de iş dışında insan kendinin hâkim ve örgütlemediği bir yer ve zamandadır (Erdoğan 2009, s.14). Bu doğrultuda birey adeta kapitalizmin öngördüğü postmodern evren içerisinde ihtiyacı olsa da olmasa da tüketmek zorunda kalmakta ve kendisini belki de ancak tüketerek rahatlatmakta ve sisteme adapte olmuş hissetmektedir.

\section{Sonuç}

Yaşadığımız dünya kontrolümüzde olmaksızın tüketimci olma yolunda ilerlemektedir. Aşırı harcamalar ve lükse ayağını dayayan toplum, adeta tüketmekle vazifelendirilmiş gibi davranmaktadır. Zihninde hayal ettiği dünyada, bir özgürlük durumu içerisinde olduğunu düşleyerek elleri cebinde 1slık çalıp gezen görece alt sosyo-ekonomik kesim, harcarken, asıl ıslık çalarak mutlu olanların, tüketimi yönlendirenler olduğunun farkına varamamaktadır.

Günümüzde kapitalizmin tüketilmediğinde ne yapacağıyla ilgili bir çözümü henüz bulunmamaktadır. Üretmek için tüketmek zorunlu görünmektedir. Bu bağlamda çalışanların boş zamanlarını tatillerde, turlarda, hobi kurslarında ve çeşitli sosyalleşme mekânlarında harcayarak geçirmeleri istenmektedir. Tasvir ettiğimiz yaşam biçiminin tamamen serbest piyasa ekonomisi içerisinde, bireylerin özgür seçimleri olduğunu düşünmek, bu davranışa sevk eden birçok faktörü göz ardı etmek olur.

Kapitalizm ve tüketim döngüsüne baktığımızda kuşkusuz medyanın kapitalizm ve tüketim kültürü üzerindeki etkisi yadsınamaz. Medya tüm içerik ve pratikleri ile postmodern dünyada popüler kültürü bir yaşam biçimi gibi gösterip, somut ya da soyut fark etmeksizin birçok emtiayı sunmaktadır. Böylelikle medya kadar, medya aracılığı ile bireylere ulaşmak isteyen reklam verenler gibi kimselerin de bireylerin tüketmelerini arzulama hedefleri gerçekleşmektedir. Medyanın ürettiği dizi, haber ve yarışma programları ile reklâmlar gibi medya içerikleri bireylere yeni ve moda olanı sunmaktadır. Birçok medya içeriğinin işaret ettiği yaşam biçimleri, kişilik biçimleri, gündelik yaşam pratikleri, ürünler, giyim ve yeme-içme alışkanlıkları popüler bir hal almaktadır. Fiske'nin popüler haz kavramı ile işaret ettiği gibi, bireyler medya 
tarafından popüler olana ya da popüler olarak işaret edilene adapte olarak kendilerini iyi hissettirmekte ve tüketimden bir haz almaktadır. Bu yüzden medya içeriklerinin etki boyutu en çok da tüketim tartışmaları noktasında kendini göstermektedir.

İzler kitlenin tüketim ürünlerine nasıl yanıt verdikleri ya da reklâmlar konusunda satın alma davranışlarına odaklanan tüketim davranışı kavramı da temelde kitle iletişim araçlarının etkisini ölçmeyi amaçlarken, aynı zamanda tüketimin tüm boyutlarını da gözler önüne sermektedir (Mutlu 2004, s.286). Yine günümüzün yaygın ve iddialı varsayımlarından biri, bireylerin medya içerikleri ile iletişimsel ya da kapitalist emtiaları değil, aslında kendi kendilerini yani kendi kültürel pratiklerini tükettikleridir. 1980'lerden beri hız kazanan ve küreselleşme ile birlikte doruk noktasına ulaşan iletişim teknolojileri, yeni ve sosyal medya boyutlarıyla kitlesel katılım ve tüketimle bireyleri iletişim sürecinin bizzat içine dâhil ederek davet etmektedirler. Çünkü bireyler medya içerikleri ile hem maddi ihtiyaçlarını gidermekte, hem de kimlik ya da benlik edinme gibi manevi ihtiyaçlarına çözüm aramaktadırlar. Görüyoruz ki aktif olarak kendi yaşamında söz sahibi olamayan insan, kendisine kimlik kazandırmayı harcamalarında ifade etmektedir. Zorunlu olarak yapılması gereken tüketimi bir statü ve ayrıcalık kazanma ifadesi olarak anlamlandırmaktadır. Tüketmeyen birey kapitalist ve postmodern dünya içerisinde kendisini sistemin dışında hissetmekte ve tüketimciliği etrafını dört koldan saran tüketim yönlendirmeleri ile gitgide kanıksamaya başlamaktadır.

Görünen o ki, günümüz insanları; üretim-tüketim ilişkisinde Foucault'nun Hapishanenin Doğuşu'unda anlattığı “Panaptikon'u gibi üzerinde dolaşan gözleri fark edememektedir. Birbiriyle sarmallanan üretim ve tüketim faaliyetinin sürekliliği ancak beraber hareket etmeleriyle mümkün olabilecektir. Bunun için kulede ürün ve hizmetlerinin satılmasını isteyenler gözeten olmaktaki konumunu kaybetmeyip, tüketici kitle üzerindeki kontrol işlevini medya ve moda gibi soyut iletişim araçlarını kullanarak sürdürmeye devam edeceklerdir. 


\section{Kaynakça}

ADORNO, W. T. (2003) Kültür endüstrisini yeniden düşünürken. Çev. Bülent O. Doğan. Cogito, 36, Yaz.

ADORNO, W. T. (2007) Kültür endüstrisi kültür yönetim. Çev. Mustafa Tüzel, Nihat Ünler ve Elçin Gen. İstanbul: İletişim Yayınları.

AYDOĞAN, F. (2009) Tüketim kültürünün gölgesinde kentler. Marmara Üniversitesi İ.̇.B.F Dergisi, 27 (2), s. 203-215.

AYTAÇ, Ö. (2002) Boş zaman üzerine kuramsal yaklaşımlar. Fırat Üniversitesi Sosyal Bilimler Dergisi, 12 (1), s. 231-260.

AYTAÇ, Ö. (2004) Kapitalizm ve hegemonya ilişkileri bağlamında boş zaman. Cumhuriyet Üniversitesi Sosyal Bilimler Dergisi, 28 (2), s. 115-138.

BALİ, R. N. (2002) Tarzı hayattan Life Style'a yeni seçkinler yeni mekânlar yeni yaşamlar. 2.Baskı. İstanbul: İletişim Yayınları.

BAUDRILLARD, J. (2004) Tüketim toplumu. Çev. Hazal Deliceçaylı ve Ferda Keskin. İstanbul: Ayrıntı Yayınları.

BAUDRILLARD, J. (2000) Kötülü̈̆̈̈̈n şeffaflı̆̆̆. Çev. Işık Ergüden. İstanbul: Ayrıntı Yayınları.

BAUDRILLARD, J. (2003) Simülakrlar ve simülasyon. Çev. Oğuz Adanır. 2. Basım. Ankara: Doğu Batı Yayınları.

BAUMANN, Z. (1999) Çalı̧ma, tüketicilik ve yeni yoksullar. Çev. Ümit Öktem. İstanbul: Sarmal Yayınevi.

BAUMANN, Z. (2009) Akışkan aşk/insan ilişkilerinin kırılganlığına dair. Çev. Işık Ergüden. İstanbul: Versus Yayınları.

BAUMANN, Z. ve LYON, D. (2013) Akışkan gözetim. Çev. Elçin Yılmaz. İstanbul: Ayrıntı Yayınları.

BELK, R. W. (1988) Possessions and the extended self. Journal of Consumer Research, 15, s.139-168.

BOCOK, R. (1993) Tüketim. Çev. İrem Kutluk. Ankara: Dost Kitabevi.

BOURDIEU, P. (2006) Pratik nedenler. Çev. Hülya Uğur Tanrıöver. İstanbul: Hil Yayın.

BULUNMAZ, B. (2013) Postmodern dünyanın gerçeküstü mekânları: sosyal paylaşım siteleri. 1.Baskı. İstanbul: Reklâm Yaratıcıları Derneği \& Grafik Tasarım Yayınları.

CHOMSKY, N. (2012) Medya gerçeği. Çev. Abdullah Yılmaz ve Osman Akınhay. 4. Basım. İstanbul: Everest Yayınları. 
ÇETINER, Ö. ve ERDAL, Ö. (2009) 1980 Sonrası Türkiye'de finansallaşma ve tüketim: Fordizm'in tutarlı bir alternatifi mi? 17-19 Haziran Eskişehir Econ Anadolu 2009 Anadolu Uluslar arası İktisat Kongresi'nde sunulmuş tebliğ.

DAĞTAŞ, B. ve DAĞTAŞ, E. (2006) Tüketim kültürü, yaşam tarzları, boş zamanlar ve medya üzerine bir literatür taraması. Ĕ̆itim Bilim Toplum Dergisi, 4 (14), s.303349.

DEBORD, G. (2014) Gösteri toplumu. Çev. Ayşen Ekmekçi ve Okşan Taşkent. İstanbul: Ayrıntı Yayınları.

ECEVİT. Y. (2001) Türk romanında postmodernist açılımlar. İstanbul: İletişim Yayınları.

ERDOĞAN, İ. (2009) Materyal ve düşünsel hayatın üretimi ve yabancllaşma. Bilim ve Ütopya, (182), s. 9-16.

FEATHERSTONE M. (1996) Postmodernizm ve tüketim kültürü. Çev. Mehmet Küçük. İstanbul: Ayrıntı Yayınları.

FISKE, J. (2012) Popüler kültürü anlamak. Çev. Prof. Dr. Süleyman İrvan. İstanbul: Parşömen Yayınları.

HOBSBAWM, E.J. (2013) Sanayi ve imparatorluk. Çev. Abdullah Ersoy. 5. Baskı, Ankara: Dost Kitabevi.

HÜRMERİÇ, P. ve BABAN, E. (2012) Simmel, Veblen ve Sombart'in penceresinden hedonik tüketim: ütopyada Negotium ve Otium. Global Media Journal TR Edition, 2 (4), s. 87-101.

IGGERS, G. G. (2000) Bilimsel nesnellikten postmodernizme yirminci yüzyılda tarih yazımı. Çev. Gül Çağalı Güven. İstanbul: Tarih Vakfı Yurt Yayınları.

JAMESON, F. (1991) Postmodernism or the cultural logic of late capitalism. Durham, NC: Duke University Press.

KAYA, K. ve OĞUZ, N. Z. (2010) Üniversite gençliğinin alışveriş tercihlerinde tüketim kültürünün rolü. SDÜ Fen Edebiyat Fakültesi Sosyal Bilimler Dergisi, (22), s.147-164.

LASN, K. (2004) Kültür bozumu: sonumuzu hazırlayan tüketim çllgınlı̆̆ından kurtulmanın yolları. Çev. Cem Pekman ve Ahmet Ilgaz. İstanbul: Bağımsız Yayınları.

LYOTARD. J. F. (2013) Postmodern durum. Çev. İsmet Birkan. Ankara: BilgeSu Yayıncılık.

MARCUSE, H. (1997) Tek boyutlu insan: ileri işleyim toplumunun ideolojisi üzerine incelemeler. Çev. Aziz Yardımlı. İstanbul: İdea Yayınevi.

MARX, K. (1993) Kapital 1. cilt kapitalist üretimin eleştirel bir tahlili. Çev. Alaattin Bilgi. 4. Baskı. Ankara: Sol Yayınları.

MUTLU, E. (2004) İletişim sözlüğ̈̈̈. 4. Basım. Ankara: Bilim ve Sanat Yayınları. 
ODABAŞI, Y. (2004) Postmodern pazarlama. İstanbul: Kapital Medya Hizmetleri.

ÖNCEL, M. (1969) Ekonomik istikrarı teminde para ve maliye politikalarının rolü. Ankara Üniversitesi Hukuk Fakültesi Dergisi, 26 (3), s.289-300.

ÖNGEN, T. Tekelci (1993) Kapitalizm ve sınıf yapısı. Ankara Üniversitesi SBF Dergisi, 49 (3-4), s. 303-349.

ÖZBEK, Y. (2005) Postmodernizm ve alımlama estetiği. Ankara: Çizgi Kitapevi.

ÖZCAN, B. (2007) Rasyonel satın alma ve boş zaman sürecine ait alışveriş eylemlerinin birlikte sergilendikleri mekânlar: alışveriş merkezleri. Afyon Kocatepe Üniversitesi Sosyal Bilimler Dergisi, 9 (2), s.39-68.

ROSANVALLON, P. (2004) Refah devletinin krizi. Ankara: Dost Kitabevi.

SENNETT, R. (1996) Kamusal insanın çöküşü. Çev. Abdullah Yılmaz ve Serpil Durak. İstanbul: Ayrıntı Yayınları.

SEVIM, A.B. (2010) Walter Benjamin'in kavramlarılla kültür endüstrisi: "aura”, “öykü anlatıcısı" ve "flâneur". Uluslararası Sosyal Araştırmalar Dergisi, Sayı 3(11), s. 509516.

SIMMEL, G. (1996) Metropol ve zihinsel yaşam, kent ve kültürü. Cogito, 8, s. 81-89.

STEVENSON, N. (2008) Medya kültürleri sosyal teori ve kitle iletişimi. Çev. Göze Orhon ve Barış Engin Aksoy. İstanbul: Ütopya Yayınevi.

ŞAHİN, E. Ç. (2009) Tüketim toplumu: 'Mükemmele evrilen politika. DAĞTAŞ, B ve DAĞTAŞ, E. (der.) içinde. Medya, tüketim kültürü ve yaşam tarzları. Ankara: Ütopya Yayınevi, s.103-141.

ŞAN, M.K. ve HİRA İ. (2004) Modernlik postmodernlik bağlamında tüketim toplumu kuramları. Bilgi Dergisi, (8), s. 1-20.

ŞAN, M. K. ve HİRA, İ. (2011) Frankfurt Okulu ve kültür endüstrisi eleştirisi. http:/ / www.politikadergisi.com/sites / default / files / kutuphane/ frankfurt_okulu_ve_ kultur_endustrisi_elestirisi.pdf.

ŞENTÜRK, Ü. (2008) Modern kontrol: tüketim. Cumhuriyet Üniversitesi Sosyal Bilimler Dergisi, 32 (2), s. 221-239.

TAYMAZ, E. (1993) Kriz ve teknoloji. Toplum ve Bilim Dergisi, 56-61, s.1-42.

THOMPSON, J. B. (2008) Medya ve modernite. Çev. Serdar Öztürk. İstanbul: Kırmızı Yayınları.

YAYLAGÜL, L. (2006) Kapitalizm, medya, popüler kültür ve ideoloji. YAYLAGÜL, L. (der) içinde Kitle iletişiminin ekonomi politiğ̈i. Ankara: Dalbaz Yayıncılık, s. 289-326.

YENTÜRK, N. (1993) Post-Fordist gelişmeler ve dünya iktisadi işbölümünün geleceği. Toplum ve Bilim Dergisi, 56-61, s. 42-58. 